\title{
The Promise of an Accumulation of Care: Disadvantaged African- American Youths' Perspectives About What Makes an After School Program Meaningful
}

\author{
Jeffrey J. Bulanda \\ Aurora University, jbulanda@aurora.edu \\ Katherine Tyson McCrea \\ Loyola University Chicago, ktyson@luc.edu
}

Follow this and additional works at: https://ecommons.luc.edu/socialwork_facpubs

Part of the Social Work Commons

\section{Author Manuscript}

This is a pre-publication author manuscript of the final, published article.

\section{Recommended Citation}

Bulanda, Jeffrey J. and McCrea, Katherine Tyson. The Promise of an Accumulation of Care: Disadvantaged African-American Youths' Perspectives About What Makes an After School Program Meaningful. Child and Adolescent Social Work Journal, 30, 2: , 2013. Retrieved from Loyola eCommons, Social Work: School of Social Work Faculty Publications and Other Works, http://dx.doi.org/10.1007/ s10560-012-0281-1

This Article is brought to you for free and open access by the Faculty Publications and Other Works by Department at Loyola eCommons. It has been accepted for inclusion in Social Work: School of Social Work Faculty Publications and Other Works by an authorized administrator of Loyola eCommons. For more information, please contact ecommons@luc.edu. (c) (i) $\left(\ominus_{\mathrm{NY}}\right.$

This work is licensed under a Creative Commons Attribution-Noncommercial-No Derivative Works 3.0 License. (C) Springer Science \& Business Media B.V., 2013. The final publication is available at http://link.springer.com/ journal/10560. 
The Promise of an Accumulation of Care:

Disadvantaged African-American Youths' Perspectives about What Makes an After School Program Meaningful

Published in: Child and Adolescent Social Work Journal, 2013 


\section{Introduction}

This study reports on preliminary findings from an ongoing participatory action project providing after-school leadership development services for disadvantaged African-American youth, a program termed Stand Up Help Out (SUHO, www.standuphelpout.org). The program aims to develop youths' capacity for constructive relatedness with adults, peers, and younger children. Increased capacity for constructive relatedness can strengthen their personal and professional competence, despite the considerable challenges they face of poverty, community violence, educational disadvantage, social exclusion, and racial discrimination. The SUHO services evaluated here were developed from Summer, 2006 through Fall, 2007 by systematically honing services in response to youth feedback. Services offered youth three levels of care: individual personal and career counseling, peer support, and opportunities to constructively remedy community problems, such as mentoring elementary school children.

Responding to priorities generated by previous after school program researchers (Deschenes et al., 2010; Durlak \& Weisberg, 2007; Granger \& Kane, 2004; Halpern, 2006; Proscio, 2003; Proscio \& Whiting, 2004), who call for programs to improve youth engagement and better understand how to develop youths' constructive relationship abilities, the research reported here addresses three central questions:

1) What do disadvantaged African-American youth find most valuable about after school program services?

2) How can we understand, given previous research and youths' feedback, the nature of the constructive relationship skills that an after school program can develop in disadvantaged youth?

3) What does the process of developing those constructive relationship skills look like from the youths' perspectives? 


\section{Background: Priorities for After School Programs for Disadvantaged Youth}

\section{Trauma and Risks}

By comparison with youth in privileged environments, severely disadvantaged youth experience higher rates of community violence (Osofsky, Wewers, Hann \& Fick, 1993; Richters \& Martinez, 1993; Schwab-Stone et al., 1995), hostility and aggression within their schools (Laub \& Lauritsen, 1998), domestic violence (Raphael \& Tolman, 1997), child abuse and neglect (Coulton, Korbin, Su \& Chow, 1995; Drake \& Pandy, 1997), and disrupted parental attachments (Bolland, McCallum, Lian, Bailey, \& Rowan, 2001; Fox, Connolly \& Snyder, 2005; Leventhal \& Brooks-Gunn 2000, 2003). The symptoms resulting from such traumatizing experiences can include suicidal and homidical ideation, substance abuse (Clark, Lesnick, \& Hegedus, 1997), dangerous sexual practices (Voisin et al., 2007), pervasive anxiety, hopelessness and helplessness about changing their futures, difficulty thinking clearly, increased risk-taking behaviors, physical aggression in response to interpersonal conflict, impairments in attachment, affect regulation, memory and concentration, learning, and self-concept. Even just a few of those serious symptoms interfere with youths' competence in the workplace and personal life (Cook et al., 2005; Garbarino, Dubrow, Kostelny, \& Pardo, 1992; Schwab-Stone et al., 1995). Clearly, youth living in high-risk environments must have opportunities to experience healthy relationships to prevent lasting post-traumatic reactions, provide healthy exemplars, and offer healing relational experiences - but such services tend to be in short supply in their communities.

Taylor (1989) found that many of the inner city teens he studied were not able to identify individuals they regarded as role models in their lives. He reported that the youth stated they wanted to 'be myself' and had little interest in forming relationships with potential role models, 
resulting from a lack of trust and confidence in their social environment and current social network. The youth, rather, turned to their peers as their primary source of interpersonal support and influence, making them even more prone to gangs and other negative peer influences. Even in a context as seemingly different as Lithuania, youth in conflict with the law stated their sources of support were almost exclusively from street peers rather than from family, relatives, or teachers (Rimkus, 2011).

The Potential of After School Programs

Researchers have noted that rather than searching for one 'magic bullet,' effective interventions need to build up an accumulation of protective factors to develop youths' resilience (Masten \& Coatsworth, 1998). Yet, disadvantaged African-American youth, in particular, experience more social exclusion from supportive social services, despite their considerably greater risks for suffering consequences of multiple psychosocial traumas. For instance, attrition from mental health services for disadvantaged African-American youth ranges from $30-60 \%$ (Kazdin, 2003). After-school programs have great potential for helping to remedy the social exclusion of disadvantaged youth, as they are potentially are less stigmatizing than formal mental health services and could be better venues for outreach. However, a comprehensive effort to strengthen after-school program resources in three cities termed MOST (Halpern, Spielberger, \& Robb, 2001) concluded that many more effective after-school programs are needed, as only 10$15 \%$ of disadvantaged youth participated in such programs. A decade later, the relative shortage of after school programs for disadvantaged youth has continued, as reported in a recent survey of programs in six cities (Deschenes et al., 2010).

After school programs can play a valuable role in supporting disadvantaged youths' abilities to cope with the stressors they face. As Halpern (2006) notes, after school programs 
have existed for over 100 years, have had numerous emphases (the arts, physical education, academic, civic, etc.), and have been applied with children and youth of all ages.

One reason after school programs can be helpful is because they provide participating youth with opportunities for mentoring by instructors. Research indicates mentoring relationships can bring about significant changes in the lives of the mentees, impacts that are mediated by a number of factors, including the youth's interpersonal history, social competencies, developmental stage, relationship duration, program practices, family context, and neighborhood ecology (Rhodes, 2002, 2005). The cornerstone of an effective mentoring relationship is a strong interpersonal connection characterized by mutuality, trust, and empathy. This connection is built over time ${ }^{1}$ as,

It seems more likely that successful mentoring of youth is more often characterized by a series of small wins that emerge sporadically over time. Yet these mundane moments, which might be laced with boredom, humor, and even frustration, can help forge a connection from which the mentee may draw strength in moments of vulnerability or share triumph in moments of accomplishment. (Rhodes, 2005, p. 32)

What makes mentoring relationships work? Taking an historical perspective to address this question, as early as 1935 the child psychoanalyst and educator August Aichhorn, in his book Wayward Youth, described how the seemingly simple act of having a caring conversation while walking home with a troubled teenager on a regular basis could help the youth develop needed internal psychological structure, surmount developmental difficulties, and resume a more normal development track. Adolescence, as subsequently formulated within a psychoanalytic framework by Peter Blos (1979), presents a unique opportunity for the person to become an individual by separating psychologically from dependency on parental relationships -- a "second individuation" after the first one accomplished hopefully, as Mahler, Pine \& Bergman (1975)

\footnotetext{
${ }^{1}$ In this regard, the Stand Up! Help Out! program actively seeks to develop long-lasting mentoring relationships, as youth are eligible to return to subsequent programs. Youth who are not currently apprentices are encouraged to come back for additional supports, such as assistance with resume-writing, letters of recommendation, etc.
} 
point out, during the toddler years, which should result in a "lifelong identity" (p. 109).

Optimally, during the second individuation process the adolescent consolidates ego stability, the capacity to love those outside the family, and reliable self-esteem conferred by the ideals of a flexible yet consistently strong superego (Blos, 1979). In order to accomplish those psychological developments, adolescents manifest a number of phase-specific intense needs. Perhaps most importantly for understanding the potential impact of after-school and mentoring programs is that adolescents experience an intense "object hunger" for peer and adult relationships outside the family (Ibid, p. 160). The extra-familial relationships established during adolescence can foster renewed internalization of the positive aspects of the early childcaregiver experience, and support adolescents' consolidation of an identity differentiated from dependency on family relationships.

More recently, the extensive longitudinal study by L. Alan Sroufe and colleagues at the University of Minnesota (Sroufe, Egeland, Carlson, \& Collins, 2005) documents how aspects of early experience, such as "working models" (their term, following Bowlby) of self and caregiver internalized in infancy, determine connectedness in relationships and predict adolescents' capacities for stable intimacy and academic accomplishment. While they found that many aspects of the "working models" appear to develop in a straightforwardly linear fashion from early childhood experiences, their findings also led them to posit an "organizational development" view of the mind. They emphasize that personality capacities also are emergent, evolving from contemporary relationships and from individuals' experiences of their own agency.

Building on the developmental approaches of Blos and Sroufe et al., one can speculate that after school programs with strong emphases on stimulating positive peer experiences and 
supportive mentoring can have preventative and even therapeutic effects for disadvantaged adolescents. Those youth who experienced very positive early caregiver-child relationships, with a healthy attachment and separation-individuation process, can find support for their ageappropriate efforts to organize identities for themselves that are differentiated from their families of origin. Those youth who may have suffered more traumatizing early relationships may use the after-school program supports to experience competence and connectedness, and to explore developmental tasks with help not otherwise available for them. The rich relationship support made possible in after-school programs and mentoring relationships thus can have considerable value in preventing maladaptive responses to the challenges of adolescence, especially for those youth who may have suffered developmental stressors such as parental neglect or abuse.

Coming up to the present, there is considerable need for more specific research about how mentoring can best be organized to support adolescents' healthy development. After completing a comprehensive review of literature on mentoring relationships, DuBois \& Karcher (2005, p. 8) stated that, "At present, interrelationships between theory, research, and practice are lacking in many important respects and thus in need of greater cultivation." Rhodes (2005) also argued that further research needs to address the question, "How does mentoring work?" Hirsch \& Wong (2005) commented that mentoring relationships in after school programs are different than formal mentoring programs, and recommended that researchers use a variety of methods to study after school programs, include diverse environmental settings, and study the impact of program organizational structure on after-school mentoring (p. 373-374).

Evaluating after school programs is complicated given the different community contexts and students the programs serve, which greatly multiply the variables impacting youth. Moreover, compared to other fields such as early intervention, there has been a relative lack of 
applied research about after school programs (Halpern, 2006). Studies that have evaluated afterschool programs ranged from an intensive study of the beginnings of After School Matters in Chicago (the program funding SUHO [Proscio, 2003]), to a large-scale meta-analysis of 73 experimental research design program reports (Durlak \& Weissberg, 2007), to a report of after school programs in 4 cities (Proscio \& Whiting, 2004), and a recently completed mixed methods investigation of 200 programs in six cities (Deschenes, et al., 2010). All found after school programs are cost-effective and have numerous positive effects. In one study, participating youth improved grades and graduation rates and reduced failure and drop-out rates by comparison with themselves prior to participation and by comparison with non-participating youth (Goerge, Cusick, Wasserman, \& Gladden, 2007). After school programs reduced by onesixth the likelihood that high school freshman boys would be involved in a crime (Newman, Fox, Flynn, \& Christeson, 2000, p. 10). In sum, findings that after-school programs can improve youths' academic and personal outcomes are now no longer in question.

However, Halpern (2006), arguably the leading researcher in the field, emphasized that a broad-brush approach in which dozens of programs are studied using "off the shelf" measures, grades, and test scores cannot maintain fidelity to participants' cultures, specific developmental needs, community contexts, and individual program variations. In fact, Halpern (2006) called conclusions based on such approaches "The big lie." Instead, he and other researchers (Durlak \& Weissberg, 2007; Proscio \& Whiting, 2004) have called for more in-depth studies of programs with specified populations, to understand, with fidelity to the participants' specific contexts and developmental processes how after-school programs can best achieve positive outcomes for youth. Understanding how to promote youths' participation is vital, since as Granger and Kane (2004) note, programs cannot be effective if students do not attend (they had 
found that average after-school program attendance by elementary and middle school students was only 1-2 days per week). Priorities generated by other researchers are to understand what children and youth participants experience as meaningful, in order to foster their engagement (Deschenes et al., 2010) and to understand more about how after school programs can help students develop specific relationship skills (Durlak \& Weissberg, 2007).

Here we respond to those priorities, as this is an in-depth study of a single program, focusing on the perspectives of children and youth about services, so as to better understand how to promote student engagement and the development of their relationship skills. Because participatory action research methods have a track record of effectively reducing social exclusion of disadvantaged youth from social services (Macran, Ross, Hardy, \& Shapiro, 1999), we combined a participatory action and qualitative approach. Youths' perspectives offer important insights for service planners and researchers, especially since the majority of after school program researchers have studied youths' behavior or test scores (a $3^{\text {rd }}$ person perspective), rather than seeking youths' opinions about services (a $1^{\text {st }}$ person perspective). Selfdetermination theory (Ryan \& Deci, 2008; Ryan, Stiller, \& Lynch, 1994), relationship-focused psychodynamic theory (Solomon \& Siegel, 2003; Wallin, 2007) and trauma treatment theory (Courtois \& Ford, 2010) provided the theoretical contexts for program planning and evaluation. We termed the constructive relationship capacities to be influenced by the program caregiving heuristics: Psychological structures that ground individuals' decisions in caring for themselves and others (XXX, 2008, 2010). These theoretical foundations are further discussed below. 


\section{The Program and the Participants}

\section{Stand Up Help Out}

The adolescent leadership development program, Stand Up Help Out! (SUHO) is an apprenticeship in social work for African-American youth residing in socioeconomically disadvantaged neighborhoods. Training the youth in principles of the profession of social work, SUHO focuses on helping youth respond actively and constructively to the many challenges of living in a poverty-level community. To develop youths' professional skills, SUHO treats program participation like employment: The apprentices interview for positions, are paid a stipend (averaging \$400 during 2006-2008), and are expected to learn and maintain professional standards of conduct (per After School Matters, the program's primary funder since 2006). Typically, summer programs last for six weeks and meet five days a week for four hours a day. School-year programs last 10 weeks and meet 3-4 days a week for a total of 9 hours per week. SUHO was first funded in 2006, during a time of forced community fragmentation, as public housing was being torn down and replaced with mixed-income housing to which most youth could not be admitted (Venkatesh \& Celimli, 2004). SUHO is youth-led: Youth actively plan program goals and activities, evaluate the program (for instance, by interviewing each other to gather opinions about program strengths and weaknesses, see Appendix), and contribute to future program design. After an initial period in which we carried out a community needs assessment and conducted three pilot SUHO programs for one year, refining them in response to youths' feedback, we systematically studied the impact of two (Summer and Fall 2007) SUHO programs on the variable of youths' capacities for constructive relating (defined more specifically below). 
The youth were remarkably productive. Major accomplishments of Summer, 2007 youth were learning non-violent conflict resolution strategies, authoring Beyond the Stars (a social skills curriculum for elementary school children), teaching and mentoring forty elementary-age children, creating a documentary about using nonviolent strategies to respond to community violence, and completing two college tours and an updated resume. Participants in the Fall program also went on college tours, completed resumes, learned about non-violent conflict resolution, mentored 60 elementary school children, and planned community health and safety fairs.

Team building was a central component in achieving these accomplishments. All projects required teamwork and all participants had opportunities for leadership on the various committees. A weekly "sharing circle" took place. During this time, they were able to share personal beliefs, stories, and concerns ranging from "favorite food" to "biggest insecurity." This was also a time for the youth to give feedback about the strengths and needs of the programming as well as to participate in strategic planning (i.e., what the group wanted to accomplish in future programs).

The SUHO program prioritized providing supportive counseling to youth, especially those who reported traumas verbally or conveyed their need non-verbally (by withdrawal or context-inappropriate aggression). Instructors were M.S.W. school social workers and/or graduate students in social work, who in turn received clinical supervision from a supervisor with more than 25 years clinical social work experience with children and youth. Youth also received counseling as-needed by graduate-level social work interns. ${ }^{2}$ Instructors developed

\footnotetext{
${ }^{2}$ SUHO instructors and interns thus had much more education and specific training in counseling, compared to most after-school program instructors, whose highest educational credential tend to be high school diplomas (Halpern, 2006).
} 
goals for individual personal and professional development with the youth, and also provided counseling as needed.

Involving the youth thoroughly in program design, evaluation, and proposal conceptualization may have contributed to the program's appeal and youths' attendance, as SUHO program attendance rates were 88\% (Summer 2007) and 90\% (Fall, 2007), quite high compared to other after school programs. For instance, Deschenes et al. (2010) in their survey of 200 after school programs in six cities, defined high participation as 70-79\%. (In SUHO, attendance meant that students were only allowed three absences and were expected to be punctual, carry out responsibilities, and handle peer relationships without fighting). Whereas in Chicago in 2005, about twice as many youth applied for After School Matters Programs as there were spaces available (Proscio \& Whiting, 2004), SUHO regularly had four times as many youth applying as could be accepted. Youth also voted with their feet by attending more than one program, as 15 (47\%) chose to participate in both Summer and Fall 2007 programs, deemed a high level of retention compared to other programs for older youth by Deschenes et al. (2010).

\section{Participant Characteristics}

There were 32 African-American participants in the research reported here, aged 14-16, all residing in poverty-level communities. ${ }^{3}$ While all SUHO youth had sufficient motivation to seek out and regularly attend an after-school program, all were exposed to potentially traumatic events in their homes and/or communities. Many of the SUHO students were in schools that had been evaluated as among the worst in a city that in turn has some of the worst schools in the country (facing challenges such as that $85 \%$ of Chicago's public school students are from lowincome families, cited in Proscio, 2002). The SUHO apprentices' reported problems including a

\footnotetext{
${ }^{3}$ In concert with codes of ethics and human subjects regulations, confidentiality is protected by using pseudonyms and disguising potentially identifying information.
} 
lack of textbooks, gang warfare in school hallways, and hostile and sexually seductive school staff. All 32 SUHO participants had witnessed a fatal act of community violence and/or had a family member killed. The majority reported having received violent corporal punishment, 16 (50\%) reported separation from birth parents and residing in foster care or with a kin guardian, and $10 \%$ reported having been sexually abused (this percentage is probably low given that most youth did not regard seduction by a much older adult as abuse). Many often were hungry and lacked adequate housing and food. Many suffered from impaired interpersonal skills indicating traumatic reactions, ranging from being severely withdrawn to being disruptively humorous, verbally insulting, aggressive with peers, and professing pervasive mistrust.

An important context for understanding the SUHO program and its impact is the fact that youth were often being traumatized while services were occurring (despite instructors' assiduous efforts at child protection). Those traumas included educational deprivation, lack of adequate food, clothing, and shelter, being targets of muggings, gunfire, and other violence, sexual seductions by adults, and pressures to join gangs, drop out of school, and abuse drugs and alcohol.

\section{Methodology}

Conceptual Background: Self-determination Theory and Constructive Relatedness The SUHO program used self-determination theory as one conceptual foundation. Selfdetermination theory (SDT) draws from humanistic, psychoanalytic, development, behavioral, cognitive, and post-modern theories in a well-researched theory of human development and psychological change (Ryan \& Deci, 2002, 2000). SDT posits that humans experience wellbeing when interactions with their environments satisfy their needs for self-determination, understood as comprised of competence, autonomy, and relatedness (Ryan \& Deci, 2000 \& 
2002, p. 6). Competence is a person's assessment of her/his capability to successfully complete a task, a "felt sense of confidence and effectance in action" (Ryan \& Deci, 2002, p. 7). Autonomy concerns perceived internal locus of control related to choices, acknowledgment of feelings, and opportunities for self-direction (Deci \& Ryan, 2000).

Relatedness - the central part of the dependent variable in our study-refers to "feeling connected to others, to caring for and being cared for by those others, to having a sense of belongingness both with other individuals and with one's community” (Ryan \& Deci, 2002, p.

7). The concept of relatedness thus is consistent with and builds upon the contributions of Mahler, Pine \& Bergman (1975), Blos (1979), and Sroufe et al. (2005) described above. "Constructive" is added to the term relatedness for our dependent variable because youth can feel very invested in activities such as gang membership or bullying, yet those are destructive forms of relating.

SDT, like psychodynamic theories (Wallin, 2007), holds that relationships are internalized throughout the lifespan, using both conscious and unconscious processes, forming mental representations of self and other that direct an individual's perception of events and future planning (Ryan, Stiller \& Lynch, 1994). As was mentioned previously in incorporating concepts from psychodynamic, object relations, and attachment theories (Mahler, Pine, \& Bergman, 1975; Blos, 1979; Sroufe et al., 2005), adolescents in the throes of the individuation and separation process do best when they can sustain an experience of healthy emotional reliance on adults as well as on peers (Ryan, LaGuardia, Solky-Bertzel, Chrkor, \& Kim, 2005). Following SDT, we designed SUHO to maximize youths' experiences of autonomy, competence, and relatedness. This study focuses specifically on relatedness. 
Our focus on constructive relatedness draws in part from Rauner's (2000) seminal work on caring in six youth programs. She focused on developing caring behaviors, arguing that caring is a necessary context for growth and that it occurs on many levels: Spontaneous individual contacts, actions of professionals, the structure of organizations, and society (p. 3). Fundamentally, caring is "the 'stuff' behind transforming experiences and relationships... care is practice: it happens in real time, and it is tangible" (Rauner, 2000, p.19).

Constructive relatedness as defined here can be regarded as one element of what we have previously defined as caregiving heuristics: Patterned, action-oriented, value-based, structures within subjective experience comprised of four elements: 1) specific guidelines for action that are value-based, 2) "tacit" knowledge, 3) compassion and related emotions including pleasure in the developmental accomplishments of a cared-for person, and 4) problem-solving strategies related to caregiving (XXX, 2008, 2010). Here, the term heuristics refers to psychological structures that guide choice, and caregiving heuristics specifically guide caring for others and oneself. From a general psychodynamic point of view, a caregiving heuristic may be understood as an ego function grounded in identifications ("working models" following Bowlby and Sroufe et al [2005] as mentioned previously) and problem-solving processes, aimed to fulfill superego ideals about optimal caregiving which also are based in identifications with (past and present) important others. It seems likely that people develop their caregiving heuristics throughout life, but especially when they have opportunities to receive and provide caregiving.

Improving ecological validity of measurement procedures

To study SUHO, a considerable initial problem had to be addressed. While After School Program evaluation research has understandably (and valuably) typically employed standardized measures to evaluate outcome, we (like Halpern, 2006) found there were significant problems 
with the reliability and validity of such measures when applied to study the relatedness of African-American, poverty-level urban youth. Despite trying multiple scales and multiple ways of administering them, including having youth read them to each other, youth regarded the standardized scales as irrelevant and either rejected them altogether or else politely filled them out rapidly and clearly without thinking or valuing the content. Further, there were no scales available that measured exactly, in the vernacular of poverty-level urban African-American youth the youths' self-experience of their relatedness. Accordingly, to study the impact of SUHO on the youth's relatedness, it was important to develop a theory-based dependent variable that was flexible enough to be culturally relevant and researchable in the context of a participatory action, youth-led commitment, hence our focus on constructive relatedness.

Participatory Action Commitment

This research is part of an ongoing participatory action research project, which took its focus from the fact that residents in the poverty-level community in which SUHO services were offered prioritized helping their youth but refused to be involved in research because, as they put it, "people study us and walk away and our community is no better." When we asked whether we could do only research that involved them as partners and focused on their selfdetermination, the answer was a resounding "yes." In keeping with that commitment, we involved disadvantaged youth in designing and evaluating their social services, including identifying the problems the social services will remedy.

Participatory action research (PAR) is based on the value that local knowledge has distinct epistemological and political (social justice) benefits. Researchers are not spectators, but rather actively reflect upon and construct their research process (Baert, 2005). PAR maximizes the reflective contributions of participants, yielding valuable findings unobtainable using other 
methods because it reduces some of the demand characteristics that can occur when disadvantaged persons feel alienated from researchers who 'study' them as strangers (Fine \& Torre, 2006; Stringer, 2007). We aimed to focus on youths' subjective experiences so as to increase ecological validity and fidelity to their culture, which is especially important given the youths' context of racial discrimination and social exclusion (so the research does not replicate those malignant processes). A disadvantage of focusing on youth-perceived causal connections between the program services and their relatedness is that one then cannot control for variables outside the youths' awareness that could have impacted their relatedness. As one (and clearly partial at best) corrective for this problem, in data analysis we focused on youths' self-reports of their experiences of changes they attributed to participating in the program.

Applying the principles of PAR and empowerment evaluation (Fetterman \& Wandersman, 2004) made the SUHO program and research about it youth-led. Youth participated actively in identifying the community problems the program addressed, took active leadership in the program's small and large groups and in the community forums they planned and led, and at the end of the programs, interviewed each other to so as to optimize their frankness about program quality (see Appendix for interview protocol).

Data collection and analysis

Data collection occurred in several ways to maximize the benefits of triangulation. The first step was for youth to write down three reasons that they joined the program, providing information both about their motivation and expectations and providing the base for the program's mission statement. This step also introduced youth to their roles as researchers, since youth began to develop questions for the end-of-program evaluation. Three youth interviewers (who interviewed peers for the end-of-program evaluation) and two youth researchers (who 
gathered systematic field notes) were selected and trained. Each week a roundtable discussion was held to talk about how the program was running and receive feedback about the program from youth (which was transcribed by the instructors and two youth researchers). In addition, the instructors met individually with two different students each week to gain a more in-depth discussion of how the program was running; these sessions were recorded in the instructors' journals. The two instructors rotated in gathering field notes on an ongoing basis. Because the qualitative data were collected over a sustained time period, researchers could study interactional processes and assess relationships between variables as they took shape in the program (Miles \& Huberman, 1994). In the last week of the program, the three youth interviewers interviewed the youth, so that all had the opportunity to provide feedback about the impact of the program for them (see Appendix for interview protocol).

While consumer evaluations of programs are prone to the problem that consumer bias will be overly positive, there are many ways to try to regulate this bias. First, one can elicit and focus on negative comments (utilized previously in Tyson McCrea \& Spravka, 2008) during data collection and analysis, which was implemented here. Another corrective for overly positive responses to the program is that both culturally and because of their developmental stage, participating youth are inclined to be critical rather than over-idealizing. Finally, enlisting youth to interview each other allowed youth to feel more comfortable frankly sharing negative thoughts than they would have with an adult (several statements by the youth affirmed that assumption).

Using criteria for a naturalistic, qualitative program evaluation described by Williams (1986, as cited in Shaw [1999, pp. 14-15]), data were analyzed qualitatively, providing an indepth understanding of the adolescents, their context, and their experiences of SUHO and allowing us to pursue deeper aspects of questions as they arose in the data analysis (Marshall \& 
Rossman 2006). In analyzing data, we utilized both a tight approach (the pre-establishment of coding categories using, for instance, self-determination theory) and a loose approach (allowing categories to emerge from the data, Miles \& Huberman, 2004). A hierarchy of categories was developed as relationships emerged between the codes, highlighting the most prominent themes. To enhance reliability, two additional researchers coded $30 \%$ of the data (inter-rater reliability was $88 \%$ and $91 \%)$.

\section{Results}

\section{Overview}

\section{TABLE 1: YOUTHS' EXPERIENCE OF RELATEDNESS}

Theoretical Definition: "feeling connected to others, to care for and being cared for by those others, to having a sense of belongingness both with other individuals and with one's community... Relatedness reflects the homonomous aspect of the integrative tendency of life, the tendency to connect with and be integral to and accepted by others. The need to feel oneself as being in relation to others is thus not concerned with attainment of a certain outcome (e.g., sex) or a formal status (e.g., becoming a spouse, or a group member), but instead concerns the psychological sense of being with others in secure communion or unity" (Ryan \& Deci, 2002, p. 7).

Definition constructed from the youth's data:

1. Experiences of caring for others

Positive peer relationships - descriptions of loyalty and trust within the team

"The program helped everyone when we have discussions when everyone tell their problems or tell how they are feeling.'

Caring for younger children

"Everyone started off with a low relationship with the kids but now everyone is learning to get to know their children."

2. Experiences of being cared for

Feeling accepted by the team

"Yeah, like in the circle. At first, I didn't want to tell no one my business, I didn't want to talk, but I got to the point where I could tell them something and it won't be a secret no more."

Help received from instructors

"Yes, it influenced me that I can be whatever I want. And, the world is out there. Reach for the stars. Reach for the sky. Because at first, I felt like I wouldn't even be accepted into a college. And, if it weren't for [the instructors], I wouldn't know what I'd do."

3. Expression of empathy (alternatively termed compassion)

Youth are able to recognize the feeling of another peer, instructor, or mentee.

"I think helping them with their homework and playing games and getting to

know the childrens and different situations they was going through and helping

them make the situation better."

4. Relationship with the community

Youth discuss themselves and their actions in relation to their community.

"I can say it helped me cuz we trying to spread the word about the effects of this stuff and how not to use it cuz it's up and we killing ourselves by doing that stuff. In a way of making a documentary, I think we did kind of help, cuz I want the world to be drug-free and all that good stuff. You know what I mean? I pray for world 
A comprehensive review of findings from the program evaluation can be found in YYY (2008). Here, we focus on findings about the dependent variable of youths' constructive relatedness. As indicated in Table 1, four thematic sub-categories of constructive relatedness emerged: experiences of caring for others, experiences of being cared for, expression of empathy, and relationship with the community.

Mutual Relationships with Peers

The SUHO program involved peers interacting on group projects, making presentations, and engaging in social activities for the majority of time, potentially providing another positive influence (Herrera, Vang, \& Gale, 2002). Youth commented on the mutuality that developed, especially in the 'sharing circles.' They divulged stressful experiences, supported each other and trust in peers grew. Mashana wrote in her journal, “The program helped everyone when we have discussions when everyone tell their problems or tell how they are feeling...Everyone is starting to care about each others' feelings and more caring. It's starting to get smooth." Two other youth said, "When we be doing this little circle or whatever it be helping. It's good to talk," and "When we do the circle...I like how people came together and expressed some of their feelings and about life." The youth progressively shared more about their personal experiences, and the burgeoning trust seemed to spill over into the youths' other relationships.

The youths' ability to work together was improved by loyalty they increasingly felt. In response to the question, "Were there ever problems when you were working as a group?" many students were able to cite problems. However, the youth consistently relied upon their positive peer relationships,

I mean to be honest, there's always going to be a problem. Ain't nobody perfect. But, our group, our whole team, there shouldn't be nobody that shouldn't be allowed 
back [in the program]. We do an outstanding job. Like we might play or slack or argue or something, but we get our job done.

Yeah, everybody worked together. We cooperated sometimes...Yeah, there were some problems, but there weren't problems that couldn't be resolved.

We work great together. Hopefully, everybody comes back next year. I met a lot of new people and a lot of cool friends. I hope everyone can come back...At times, there were little problems. No big problems. We were always able to work it out.

I would say in all honesty that no, everybody did not get along and everybody did not participate like they should have. Somehow in the end, they always came together even though it probably did not work out in the beginning. It's like they worked together til they got it right.

Youth expressed their capacities to recognize relationship problems and focus on relationship strengths in almost all their interview responses. No participant was solely negative when describing her/his team. The data portray a group spirit of mutuality that emerged, empowering the youth to be resilient and connected despite momentary disappointments and frustrations. Kyla summed up the experience of working as a team, saying:

Everybody could come together and when we're working together and it turns out good, that my favorite part of the program. Like when we are working on a big project and everybody puts forth effort and it turns out good, that's the best part of this program.

Perhaps most striking was how the youth dealt with diversity among them, which in their communities could be a considerable trigger for strife. While most of the youth were from the same zip code, they were involved with different "street alliances." Since the program was open to all students, great diversity was also seen academic motivation and outside interests. For instance, one student was a cellist and went on to an Ivy League college, while other youth were high school dropouts or currently attending an alternative high school. The youth managed to prioritize their connectedness over the potential discord created by differences.

Caregetting Relationships with Instructors

SUHO allowed relationships with instructors to progress at the youths' pace. The group work environment allowed teens to calibrate the degree of sharing with their instructors. The 
subtle, activity-focused interactions (see Halpern 2005) allowed a foundation to be built for trusting bonds with instructors. Conversely, if youth wanted therapeutic support, the instructors were trained to provide it, and the addition of intern counselors allowed for even more individualized attention. It turned out that youth actively sought care from the instructors to help them with psychosocial needs. Many were open and impassioned about how positive personal program outcomes grew from relationships with the instructors, as illustrated by the following:

Yeah, they helped me! They helped me learn more stuff about myself. They help me deal with my attitude.

They help me with whatever I need help with. They ask me or anybody what they need help with and they will work with that person.

When I'm going through something, I can talk to them about it. That's how they helped.

For some of the youth, the relationship with the instructors was an opportunity to test out their ability to trust and use relationships to share and work through traumas they experienced. For instance, Lita was in the program for over a year and half before she disclosed early childhood sexual abuse to the instructors. Another youth, Kyra, returned to the program after dropping out for a year and used an autobiography assignment to disclose to the instructors her early physical and emotional abuse by a substance-abusing mother; in a later session, Kyra stated that the instructors earned her trust when they allowed her to come back to the program. Thus, for many traumatized youth, new internalized relationships developed over time.

The teens described several instructor qualities that helped them become attached (see Table 2). Primarily, they saw the instructors as willing to help and even go "above and beyond" their job responsibilities ("always there for me and stuff. Outside the program and stuff"). Some of youths' responses seemed to reflect a feeling that the instructors were more giving than they would have expected. This perception that the instructors were willing to help is connected to the next quality that the instructors were genuine, understanding and caring: 
She know how to get to the point of what she's trying to say even if somebody got a different opinion. She wouldn't be like 'well, what I say is right.' She would try to listen to you and see where you are coming from.

I think she's an understanding person. She'll understand you if you understand her. I think if you just go to her and talk to her, then she'll constantly make everything alright.

Also, the youth described the instructors' unconditional positive regard in the category coded, "don't let no one get on top of him." Recognizing that some of the youth were at times irritable or disrespectful to the instructors, four youth noted how the instructors did not let that negatively alter how they treated the teens. In this regard, DeShawn said: "That's what I like about [the instructor]. Cuz, even when he don't get all the respect he should get out of the kids in the program, he still be [himself]. You know calm and collective."

\begin{tabular}{|l|c|l|}
\hline \multicolumn{2}{|c|}{ TABLE 2: QUALITIES OF INSTRUCTORS } \\
\hline \multicolumn{1}{|c|}{ Quality } & $\begin{array}{l}\text { Number of } \\
\text { Responses }\end{array}$ & \multicolumn{1}{|c|}{ Example } \\
\hline $\begin{array}{l}\text { Going above and } \\
\text { beyond/ } \\
\text { Willingness to help }\end{array}$ & 12 & $\begin{array}{l}\text { "And then just listening to [the instructors] telling us about } \\
\text { stuff, even if they don't have to tell us stuff, they still do." } \\
\text { "It's just been a hard time in the program [for me] and } \\
\text { she's done more than I thought she would and she would } \\
\text { never break loose." }\end{array}$ \\
\hline "Keeps us in line" & 9 & $\begin{array}{l}\text { "She do a real good job with keeping the kids in line" } \\
\text { "She got everybody under control." }\end{array}$ \\
\hline Enthusiastic/Fun & 5 & $\begin{array}{l}\text { "IThe instructor] is energized... " } \\
\text { "'"He's always into any of the activities we have." }\end{array}$ \\
\hline $\begin{array}{l}\text { Understanding/ } \\
\text { Caring }\end{array}$ & 5 & $\begin{array}{l}\text { "I think [the instructor] understands me more than } \\
\text { anybody in this program. It's like she could see something } \\
\text { that I wouldn't probably be able to see." }\end{array}$ \\
\hline $\begin{array}{l}\text { Good teachers } \\
\text { "I think [the instructor] is a nice person, she patient, she } \\
\text { give you examples, she explains things nice." }\end{array}$ \\
\hline $\begin{array}{l}\text { "Don't let no one get } \\
\text { on top of him" }\end{array}$ & 4 & $\begin{array}{l}\text { "IThe instructor is] a cool guy. He don't let no one get on } \\
\text { top of him." } \\
\text { "That's what I like about [the instructor]. Cuz, even when } \\
\text { he don't get all the respect he should get out of the kids in } \\
\text { the program, he still be [himself]. You know calm and } \\
\text { collective" }\end{array}$ \\
\hline
\end{tabular}


The youth also seemed to value the instructors' ability to lead the program. Four apprentices talked about how the instructors were good teachers. In this category, the teens described the instructors as being knowledgeable, effective in public speaking, and able to get the point across to the teens. The teens also described how the instructors were fun and enthusiastic, saying "[the instructor] is energized," "[he] always into any of the activities we have," and "he nice, he fun and he act silly just like [the other instructor] do."

Finally, the second most common response was that the "instructors keep us in line." Here, the teens talked about the instructors maintaining structure in program, keeping the teens on task, and helping youth regulate their behavior:

"She don't really need to work on nothing. She got everybody under control";

"She doing a good job cuz she stay on us. She want us to get to get our job done, and she should keep up the good work."

Consistent with efforts to maximize youth frankness in evaluating the program, youth were able to provide critical as well as laudatory feedback for instructors. They saw the two major instructors as having very different weaknesses. Instructor 1 could be too punitive ("She do real good with keeping the kids in line, but she should be a little more patient"), while instructor 2 could be "too nice" ("I think people take advantage of his niceness. He too nice"). Interestingly, the instructors themselves tended to agree with the youths' evaluations of them.

\section{Caregiving Relationships with Younger Children}

In mentoring elementary school children, youth could be a caregiver, experiencing autonomy as they selected activities for their mentees and competence as they brought about change in their mentees. With coaching from the instructors in children's developmental needs and how to avoid abusing their authority, the teens were able to understand their mentees, elicit 
positive connections, and meet their own needs for connection and being idealized. The apprentices exhibited considerable pride in their caregiving of the younger children, and these relationships were meaningful on several levels. First, the younger children were excited to see the teens and idealized them, so the teens felt wanted and valued. Keisha said: "Yeah, I love working with them little rascals! They like me and stuff. Every time they see me, they say 'Keisha, Keisha, Keisha, Keisha!' and all that.” Mashana reported, “The little kids are amazing and they are fun to help...They really love when our group works with them."

Second, their relationships with the younger children put them in a position of authority and several teens commented on their surprise about the respect they elicited in that role: "I enjoyed it. I think it went well, cuz the kids cooperated with us. We was able to get their attention and they was well-behaved" and "I enjoyed it. It went very well. They were respectful to me. They did not curse me out." Respect seemed especially important to these youth who frequently felt disrespected in other parts of their lives.

Finally, youth stated that they felt very satisfied when they could positively connect with their mentees and influence their mentees' development for the better: "I think it went well with the kids, cuz we planned games with them and they was able to understand it. I really like that part of the program. I think it went well;" "I enjoyed working with the kids because even though they was little and younger than us, they could still comprehend and they paid attention, and I think it went well;"; "I enjoyed it cuz they understood what we was talking about and they just liked hearing what I was saying."

Developing Empathy

One of the indicators of youth's improved constructive relatedness was their capacity for empathy. The instructors regularly assessed the teens' ability to be empathic through individual 
discussions and group empathy trainings. One youth said, "I believe our confidential circles make people show their real sides. You can see how they feel and where they are coming from." The youth began to gain a better understanding of each other and felt empathy (some used the term compassion), sometimes to the point of pain, for the suffering of the profoundly disadvantaged children they mentored:

What part I didn't enjoy? I really wouldn't say I didn't enjoy a part of the program, but when we were working with the little kids, some of the stuff they were telling me. It was kinda making me feel bad when I heard what they was going through.

One teen talked explicitly about learning about empathy: "I learnt a lot...[the instructor] taught us about empathy and to put ourselves in other people's shoes. You know I learnt that, cuz before I really didn’t care."

The youth talked about the transformative nature of relationships, describing how their capacity for more intimate, attuned relationships increased during their time in the program. Consider Lenny who said, “Because, at first before the social worker stuff, I didn't really care too much about what other people thought." One young man who was raised with corporal punishment and was initially skeptical about the non-punitive philosophy of the program, said:

I learned different ways how to discipline kids. You can discipline a child by not beating on them and by not telling a child you're gonna do something to them...For example, my little sisters they be bad. I'd just get mad and them and tell them what I'd do to them. But, now that I've worked with this program, I found a different way to discipline them.

Such a profound shift in this teen's belief about taking care of younger children clearly has exciting implications for preventing future child abuse. Another young man, Lewis, said, "I learned there's other ways to discipline kids besides threatening them." One young woman summed up the impact of the program on her relatedness, saying, "It's a place where you stay out of trouble and you learn how to mentor others and you learn to be mentored yourself." 


\section{Discussion}

Youth were active, enthusiastic participants in service planning, evaluation, and research. They eagerly contributed as interviewers and service planners, and commented frankly about what they liked and did not like about the services and the instructors, helping design services with relatively high participation rates $(88-90 \%$ per program, with $47 \%$ continuing both semesters). The findings suggest that making after school programs youth-led and youthevaluated has promise for improving participation and constructive program impact for disadvantaged youth.

Since previous program evaluators 1) established the value of after school programs for improving academic and personal outcomes for disadvantaged youth (including the Chicagobased After School Matters Program that funded our SUHO services, see Proscio, 2002, 2003), 2) consistently emphasized the need for research that focuses on the perspectives of children and youth, especially those who are disadvantaged (Halpern, 2006), and 3) called for research that focuses on the variables that are associated with improving participation and youths' relationship skills (Durlak \& Weissberg, 2007; Goerge et al., 2007; Proscio \& Whiting, 2004), we focused on what, from youths' perspectives, constitute the most valuable aspects of their after school program. The youth participating in the SUHO services said that caring and being cared for was most meaningful to them, and so we focused specifically on a variable we termed constructive relatedness.

The data open a window directly into the youths' subjective experiences of their relationships with instructors, peers, and their mentees, and shed light on how the 32 participating youth believed their constructive relatedness was affected by the program. The youth consistently pointed out that giving and receiving care (they used the terms empathy and 
compassion to describe the caregiving and caregetting processes) was what they valued the most about the SUHO program. Data analysis indicated youths' constructive relatedness fell into four categories: caring for others, receiving care, developing empathy (or compassion), and constructively responding to community problems. The youths' emphasis on giving and receiving care is all the more profound given that the traumas the youth experienced would expectedly result in alienation (Cook et al., 2005). It seems, given the youths' opinions, that the investment of caring person-power and time by graduate social work instructors, social work interns, and their supervisor was a critical program element.

In the course of the program, youth sought help from the instructors and each other with ongoing traumatizing events (e.g., community shootings), difficult choices about high school graduation, and romantic and friendship commitments. Moreover, cognitive dissonance typically occurred as youth raised in conflict-ridden environments considered non-coercive ways of handling interpersonal conflict and caring for children. Youth expressed this both directly in response to group discussions (some saying initially for instance that disobedient mentees should be "whipped"), and also in their perceptions of instructors (commenting for instance that when instructors responded with empathy rather than punishment, they were "too easy"). However, as the program progressed and youth began to experience the impact of non-coercive caregiving in their interactions and carried it out in relating with their mentees, their relatedness changed and they began to describe their mentees' and peers' needs to be cared for with compassion and without coercion.

Youth described shifts in several elements of their subjective experience that comprise constructive relatedness as defined using self-determination theory. They described deeper connectedness with each other, feeling more motivated to care for their peers and others. They 
acquired new skills for caring for children, and values about handling peer relationships and caring for children without violence, punishment, and coercion. Rather than fighting or withdrawing when experiencing disagreements with others, they felt they could try to talk through problems with others. They described pleasure in giving and receiving compassion. Rather than withdraw and feel hopeless about community problems, many felt they could band together in solidarity to try to remedy them. In sum, the youth themselves believed that their capacity to care and be cared for was changed by the SUHO program.

Based on what youth told us, we posit that through multiple caring interactions, more constructive relatednesss was developed in youth. Youth stated their self-understanding and their relatedness both inside and outside the program were changed for the better by the SUHO experiences of caring and being cared for. It appears that new caregiving and caregetting relational interactions accumulated to increase the youths' capacity for constructive relatedness. The youth believed their learning about caring would be lasting, and also have the potential to change how they would respond to others, especially peers and children they would care for in the future.

Traditional program evaluations and measures of caring, while valuable, tend start from a $3^{\text {rd }}$ person perspective, such as how a person behaves towards others. The results of such measures then tend to rate individuals on behavioral dimensions, with some persons being ranked as more empathic (for instance) than others. When we focused on youth's own perspectives of their experiences of relatedness (a $1^{\text {st }}$ person perspective) in SUHO, we found that above all, they valued being cared for and caregiving. Consider that negative stereotypes of disadvantaged youth are that they are resistant to caring, unlikely to be motivated to provide care, and deficient in empathy. Perhaps those stereotypes are aggravated by research that omits 
the youth's perspectives. By contrast, in this study it was clear that all the youth sought to care and be cared for, albeit in different ways and despite different obstacles. Far from being diffident about how they treated others, the youth appreciated and eagerly sought out enhancements in their capacity for empathy and caring. A participatory action approach to program evaluation that prioritizes the perspectives of disadvantaged African-American youth can offer a corrective to negative stereotypes.

\section{Conclusion}

Living in dangerous and frightening homes and communities may lead to a range of symptomatology amongst adolescents, but for the youth participating in SUHO, such traumas could not suppress their inherent desires for relatedness and self-determination. Disadvantaged

youth can be empowered by participating in designing and evaluating the services in which they partake. Listening to the SUHO youth, the accumulation of care program design, which provides considerable supportive care for participants as well as opportunities to care for others, has promise for stimulating participation, helping youth respond constructively to profound community problems, and giving youth more constructive internal foundations for their future professional and personal relationships.

\section{References}

Aichhorn, A. $(1965<1935>)$. Wayward youth. New York: Viking Press.

Baert, P. (2005). Philosophy of the social sciences: Towards pragmatism. Cambridge, UK: Polity Press.

Blos, P. (1979). The adolescent passage: Developmental issues. New York: International Universities Press.

Bolland, J. M., McCallum, D. M., Lian, B., Bailey, C. J., \& Rowen, P. (2001). Hopelessness 
and violence among inner-city youth. Maternal and Child Health Journal, 5(4), 237-244. doi: 10.1023/A:1013028805470.

Clark, D. B., Lesnick, L., \& Hegedus, A. M. (1997) Traumas and other adverse life events in adolescents with alcohol abuse and dependence. Journal of American Academy of Child and Adolescent Psychiatry, 36(12), 1744-1751. doi:10.1097/00004583-19971200000023.

Cook, A., Spinazzola, J., Ford, J., Lanktree, C., Blaustein, M., Cloitre, M., van der Kolk, B. (2005). Complex trauma in children and adolescents. Psychiatric Annals, 35 (5), 390398.

Coulton, C., Korbin, J., Su, M., \& Chow, J. (1995). Community level factors and child maltreatment rates. Child Development, 66(5), 1262-1276. doi: 10.1111/j.14678624.1995.tb00934.x

Courtois, C. \& Ford, J. (Eds.). (2009). Treating complex traumatic stress disorders: An evidence-based guide. New York: Guilford Press.

Deci, E. L. \& Ryan, R. M. (2000). The 'what' and 'why' of goal pursuits: Human needs and the self-determination of behavior. Psychological Inquiry, 11(4), 227-268.

Deschenes, S. N., Arbreton, A., Little, P. M., Herrera, C., Grossman, J., Weiss, H., Lee, D. (2010). Engaging Older Youth: Program and City-Level Strategies to Support Sustained Participation in Out-of-School Time. Cambridge, Mass., Harvard Family Research Project and Wallace Foundation. Retrieved from http://www.hfrp.org/publicationsresources/browse-our-publications/engaging-older-youth-program-and-city-levelstrategies-to-support-sustained-participation-in-out-of-school-time-research-synopsis. Accessed 7/13/2011. 
Drake, B., \& Pandy, S. (1996). Understanding the relationship between neighborhood poverty and specific types of child maltreatment. Child Abuse and Neglect, 20(11), 1003-1018. doi:10.1016/j.physletb.2003.10.071

DuBois, D. L. \& Karcher, M. J. (Eds.) (2005). Handbook of youth mentoring. Sage Publications: Thousand Oaks, CA.

Durlak, J. A. \& Weissberg, R.P. (2007). "The impact of after-school programs that promote personal and social skills." Chicago, Illinois, Collaborative for Academic, Social and Emotional Learning (CASEL): 1-50. http://www.casel.org/downloads/ASP-Full.pdf. last accessed March, 2009.

Fetterman, D.M. \& Wandersman, A. (Eds). (2004) Empowerment evaluation: Principles in practice. New York: Guilford Press.

Fine, M. \& M. E. Torre (2006). Intimate details: Participatory action research in prison. Action Research 4, 253-269.

Fox, M.A., Connolly, B.A., \& Snyder, T.D. (2005).Youth Indicators 2005: Trends in the WellBeing of American Youth, (NCES 2005-050). U.S. Department of Education, National Center for Education Statistics. Washington, DC: U.S. Government Printing Office.

Garbarino, J., Dubrow, N., Kostelny, K., \& Pardo, C. (1992). Children in danger: Coping with the consequences of community violence. San Francisco: Jossey-Bass.

Goerge, R., Cusick, G., Wasserman, G., \& Gladden, M. (2007). Chapin Hall Report on After School Matters. Chapin Hall Center for Children: Issue Brief \#112. Chicago, Illinois, Chapin Hall Center for Children.

Granger, R. \& T. Kane (2004, Feb. 18). Improving the quality of After-School Programs. Education Week: American Education's Newspaper of Record, 23 (23). 
Out-of-School Time) Initiative: Final Report. Chapin Hall Center for Children.

Retrieved from http://www.chapinhall.org/research/report/evaluation-most-making-mostout-school-time-initiative, accessed 7/13/2011.

Halpern, R. (2005). Instrumental relationships: A potential relational model for inner-city youth programs. Journal of Community Psychology, 33(1), 11-20. doi: 10.1002/jcop.20032.

Halpern, R. (2006). Critical issues in after-school programming. Monographs of the Herr Research Center for Children and Social Policy. F. Stott. Chicago, Illinois, Erikson Institute. Vol. 1.

Herrera, C., Vang, Z., \& Gale, L. Y. (2002). Group mentoring: A study of mentoring groups in three programs. Philadelphia, PA: Public/Private Ventures. Retrieved May 15, 2008 http://ppv.org/ppv/publications/assets/153_publication.pdf.

Hirsch, B. J. \& Wong, V. (2005). After-school programs. In D. L. DuBois \& M. J.Karcher (Eds.), Handbook of youth mentoring,( pp. 364-375). Thousand Oaks, CA: Sage Publications.

Kazdin, A. (2003). Psychotherapy for children and adolescents. Annual Review of Psychology, $54,253-276$.

Laub, J. H., \& Lauritsen, J. L. (1998). The interdependence of school violence with neighborhood and family conditions. In D. S. Elliot, B. Hamburg \& K. R. Williams (Eds.), Violence in American Schools: A New Perspective (pp. 127-155). New York: Cambridge University Press.

Leventhal, T. \& Brooks-Gunn, J. (2000). The neighborhoods they live in: The effects of neighborhood residence on child and adolescent outcomes. Psychological Bulletin, 126(2), 309-337. doi: 10.1037//0033-2909.126.2.309 
Leventhal, T. \& Brooks-Gunn, J. (2003). Children and youth in neighborhood contexts. Current Directions in Psychological Science, 12(1), 27-31. doi: 10.1111/14678721.01216.

Macran, S., Ross, H., Hardy, G., \& Shapiro, D. (1999). The importance of considering clients' perspectives in psychotherapy research, Journal of Mental Health, 8, 325-337. doi:10.1080/09638239917256.

Mahler, M., Pine, F., \& Berman, A. (1975). The psychological birth of the human infant: Symbiosis and individuation. New York: Basic Books.

Masten, A. S. \& Coatsworth, J. D. (1998). The development of competence in favorable and unfavorable environments: Lessons from research on successful children. American Psychologist, 53(2), 205-220.

Marshall, C. \& Rossman, G. B. (2006). Designing qualitative research. (4 ${ }^{\text {th }}$ ed.). Thousand Oaks, CA: Sage Publications, Inc.

McCrea, K. Tyson \& Spravka, L. (2008). "I'm glad you asked": Homeless clients with severe mental illness evaluate their residential care. Journal of Sociology \& Social Welfare, 35(4), 133-159.

Miles, M. B. \& Huberman, A. M. (1994) Qualitative data analysis. (2 ${ }^{\text {nd }}$ ed.). Thousand Oaks, CA: Sage Publications, Inc.

Newman, S. A., Fox, J. A., Flynn, E. A., \& Christeson, W. (2000). America's after-school choice: The prime time for juvenile crime, or youth enrichment and achievement. Washington, DC: Fight Crime: Invest in Kids. Retrieved on September 14, 2007 at http://www.fightcrime.org. 
Osofsky, J. D., Wewers, S., Hann, D. M., \& Fick, A. C. (1993). Chronic community violence: What is happening to our children? Psychiatry, 56, 36-45.

Proscio, T. (2002). Precious Time: Report to the Field. After School Project of the Robert Wood Johnson Foundation. Retrieved from http://www.theafterschoolproject.org/uploads/Precious_Time.pdf. accessed 7/13/2011.

Proscio, T. (2003). No idle hours: Making after school time fun and productive for Chicago teenagers. New York: The After School Project. Retrieved from http://www.theafterschoolproject.org/uploads/Proscio-NoIdleHours.pdf. accessed July 11, 2011.

Proscio, T. \& Whiting, B.J. (2004). After school grows up: How four large American cities approach scale and quality in after-school programs. New York: The After School Project. Retrieved from http://www.afterschoolmatters.org/sites/default/files/AfterSchoolGrowsUp_0.pdf. accessed 7/11/2011.

Raphael, J., \& Tolman, R. (1997). Trapped by poverty/trapped by abuse: New evidence documenting the relationship between domestic violence and welfare. Ann Arbor, MI: Project for Research on Welfare Work, and Domestic Violence, a joint project of the Taylor Institute and the University of Michigan Research Development Center on Poverty, Risk, and Mental Health.

Rauner, D. M. (2000). "They still pick me up when I fall”: The role of caring in youth development and community life. New York: Columbia University Press.

Rhodes, J. E. (2002). Stand by me: The risks and rewards of mentoring today's youth. Cambridge, MA: Harvard University Press.

Rhodes, J. E. (2005). A model of youth mentoring. In D. L. DuBois \& M. J. Karcher 
(Eds.), Handbook of youth mentoring, pp. 30-43. Sage Publications: Thousand Oaks, CA.

Richters, J. E. \& Martinez, P. (1993). The NIMH community violence project: Children as victims of and witnesses to violence. Psychiatry, 56, 7-21.

Rimkus, V. (2011). Bridging the islands of society: Modeling delinquency prevention through optimization of social support. University of Lapland Printing Center, Rovaniemi, Finland.

Ryan, R. M. \& Deci, E. L. (2000). Self-determination theory and the facilitation of intrinsic motivation, social development, and well-being. American Psychologist, 55(1), 68-78. Doi: 10.1037//0003-066X.55.1.68

Ryan, R. M. \& Deci, E. L. (2002). Overview of self-determination theory: An organismic dialectical perspective. In E. L. Deci \& R. M. Ryan (Eds.), Handbook of selfdetermination research, (pp. 3-33). Rochester, NY: University of Rochester Press.

Ryan, R. M. \& Deci, E. L. (2008). A self-determination theory approach to psychotherapy: The motivational basis for effective change. Canadian Psychology, 49, 186-193. DOI: $10.1037 / \mathrm{a} 0012753$.

Ryan, R. M., La Guardia, J. G., Solky-Butzel, J., Chirkov, V., \& Kim, Y. (2005). On the interpersonal regulation of emotions: Emotional reliance across gender, relationships, and culture. Personal Relationships, 12, 145-163. DOI: 10.1111/j.13504126.2005.00106.x.

Ryan, R. M., Stiller, J. D., \& Lynch, J. H. (1994). Representations of relationships to teachers, parents, and friends as predictors of academic motivation and self-esteem. Journal of Early Adolescence, 14(2), 226-249. doi: 10.1177/027243169401400207. 
Saleebey, D. (2005). The strengths perspective in social work practice, $4^{\text {th }}$ edition. Needham Heights: Allyn \& Bacon.

Schwab-Stone, M. E., Ayers, T. S., Kasprow, W., Voyce, C., Barone, C., Shriver, T., \& Weissberg, R. P. (1995). No safe haven: A study of violence exposure in an urban community. Journal of American Academy of Child and Adolescent Psychiatry, 34(10), 1343-1352. doi:10.1097/00004583-199510000-00020.

Shaw, I.F. (1999). Qualitative evaluation. London: Sage Publications.

Solomon, M. \& Siegel, D. (2003). Healing trauma: Attachment, mind, body and brain. New York: W.W. Norton.

Sroufe, L. A., Egelund, B., Carlson, E.A., and Colins, W.A. (2005). The development of the person: The Minnesota study of risk and adaptation from birth to adulthood. New York: Guilford.

Stringer, E. (2007). Action research. Thousand Oaks: Sage Publications.

Taylor, R. L. (1995). Black youth in the United States: An overview. In R. L. Taylor (Ed.), African-American youth: Their social and economic status in the United States. (pp.334). Westport, CT: Praeger.

Venkatesh, S. \& Celimli, I. (2004). Tearing down the community. National Housing Institute: Shelterforce Online. Retrieved from http://www.nhi.org/online/issues/138/chicago.html, accessed 6/16/06.

Voisin, D. R., Salazar, L. F., Crosby, R., DiClemente, R. J., Yarber, W. L., \& Staples-Horne, M. (2007). Witnessing community violence and health-risk behaviors among detained adolescents. American Journal of Orthopsychiatry, 77(4), 506-513. DOI: 10.1037/00029432.77.4.506. 
Wallin, D. (2007). Attachment in psychotherapy. New York: The Guilford Press.

XXX (2010). Caregiving heuristics: Valuable practitioner knowledge in the context of managing residential care. Qualitative Social Work 9(3), 343-363. doi:

$10.1177 / 1473325010367818$

XXX (2008). The practice of compassion in supervision in residential treatment programs for clients with severe mental illness. The Clinical Supervisor. 27(2): 238-267. doi:

$10.1080 / 07325220802487907$.

YYY. (2008). "Real talk": Findings from a youth-led evaluation of an after school leadership development program. Ph.D. dissertation, Loyola University Chicago, United States Illinois. Retrieved October 26, 2010, from Dissertations \& Theses: The Humanities and Social Sciences Collection (Publication No. AAT 3340153).

\section{Appendix}

\section{Student-led Program Evaluation}

Teens work in pairs and interview each other, using the following questionnaire.

1. How would you describe this program to someone?

2. Why did you decide to join this program?

3. Why did you decide to keep coming to it?

4. Talk some about your favorite part of the program.

5. Talk some about a part of the program you did not enjoy.

6. We would like feedback on each part of the program.

a. What about the mentoring with the kids did you enjoy or did you think went well?

b. What about the mentoring program would you change?

7. Do you feel you learned from this program?

- If yes, what?

- If no, why do you think you didn't learn anything?

8. Did you learn anything about yourself (or your capabilities) from this program? Can you give examples? 
9. Give feedback to the instructors: Tell them how they are doing a good job and what they need to work on.

Instructor 1 (will be named in actual interview)

Instructor 2 (will be named in actual interview)

10. Do you feel the instructors helped you? If so, how?

11. Talk some about the After School Matters team - that is, you and your peers. Do you feel everyone worked together? Were there ever any problems with the team?

12. Did you feel like you were able to make decisions and contributed about the activities you participated in? Can you give some examples?

13. Did you have any opportunities to be a leader in the program? Talk some about your experiences.

14. What skills did you contribute to this program?

15. On a scale of 1-10, where 1 means you were not interested at all and 10 means you were always involved in the program, how interested would you say you were in this program?

a. Why did you give yourself that rating?

16. Why do you think that some apprentices had poor attendance at the program?

17. Has the program influenced you and your goals outside of the program?

18. Give one way for this program to be improved.

19. What would you like to do in the next program? Ideas for documentary topics? Other activities? What would you like to learn? 